\title{
不確実な需要の下での電源の最適規模構成
}

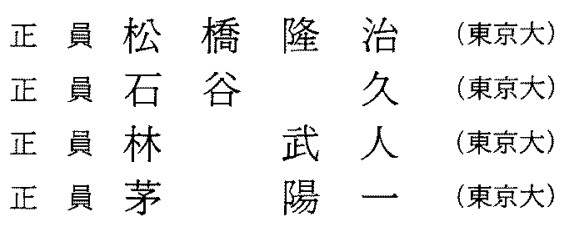

\section{The Optimal Capacities of Large and Small Scale Power Plants in the Uncertain Demand}

Ryuji Matsuhashi, Member, Hisashi Ishitani, Member, Takehito Hayashi, Member, Yoichi Kaya, Member (The University of Tokyo)

The demand for electricity in the future is uncertain and difficult to forecast. But we have to forecast the demand in the future to construct power plants. In that sence a large scale power plant has a disadvantage, since it takes long to construct it. On the other hand, a small scale one is more expensive than a large scale one, although it takes less time to construct it. Therefore large and small scale power plants could complement the disadvantages of each other. In this paper we have developed a stochastic dynamic programming model to investigate the possibility. The model determines the capacities of large and small scale power plants in the uncertain demand to minimize the expected value of the total cost. Computed results have shown that small scale plants can play a significant role in the uncertain demand even if they are more expensive than large scale ones.

キーワート゚: 需要の不確実性, 大規模電源, 分散形電源, 電源構成, 確率多段決定問題

\section{1.はじめに}

石油危機後，日本は低経済成長期に入り，エネルギ 一需要の伸びは極端に鈍化したが，ここ数年では，好 景気を反映して逆に需要が大きく伸びている。このよ うに工ネルギー需要の伸び率は乱高下しているが, 将 来への需給見通しが極めて不透明になっていることは 確かである。この需要の不確実性は, 規模の経済性の 問題と密接に関連している。例えば，電気事業は典型 的な設犕産業であり，スケールメリットを前提にして 設備の大規模・集中化が進められてきた。しかし, 石 油危機後の, 不透明な需給見通しの下で, こうした設 備投資のあり方に疑問が出始めた。また, 機器単体も しくは, 電気事業の構成要素ごとのスケールメリット は認めるとしても，それらを総合した形での経済性は 必ずしも明らかでない，という指摘がなされた。著者 らの日本のデータによる分析 ${ }^{(1)} に お$
および石炭火力発電所の建設費についてはスケールメ リットが存在するものの，そ机らの利用率については スケールデメリットがあり，送配電コストについて も，明らかなスケールデメリットが観測された。そこ で分散形電源によってこうしたデメリットを補う必要 性が指摘されている。

ガスタービンや燃料電池などの分散形電源は，パイ ロットプラント段階のものもあるが，既に実用段階の ものもあって，これらをいかにして電力系統に導入し ていくかを検討する時期にきている。また，中規模電 源の典型的な例であるモジュール形原子炉の開発も進 んでいる。現在のところ,これら分散形電源は大規模 電源と比較して建設費が割高で, 全面的に導入するこ とは難しい。しかし，これらの電源技術の急速な進歩 と量産効果を考えると，かなりの建設費の低減が期待 できる。また，分散形電源は，大規模電源と比較して 建設期間が短く(第2章で述べるように), 需要の不 
確実性への対忍が容易である。従って，規模の経済性 を構成する様々な要因を考虑した場合，大規模電源と 分散形電源が相補って，現在より柔軟で経済的な系統 を構成できる可能性がある。

呂らはこの点を考虑し，電源種が単一で規模のみ異 なる場合を想定して，建設コストを定量的に評洒する シミュレーションを行った(2)。しかし，具体的な電源 構成の中での分散形電源の導入可能性を評価し，大規 模電源との協調のあり方を検討するためには，建設賞 だけでなく傊荷持続曲線を基に算定した燃料費も考慮 に入れ，モデルを最適化形にする必要がある。

本研究では，電力部門に扔ける大規模電源と分散形 電源の協調によって需要の不確実性に柔軟に対応する 可能性を検討する。実際には，大規模と分散形電源の 二種で系統を構成し，需要の不確実性を考慮した確率 モデルを構築し, 非線形罗適化の技法によって期待コ ストが最小となる組合せを求める。その後，動的な枠 組みの中での大規模と分散形電源のシェアの変化を確 率多段决定問題として定式化し，モデルにおける大規 模電源の最適設備容量を求め, 需要の不確実性と分散 形電源導入量の関係を分析する。確率モデルと多段決 定問題を組含せた手法は以前からあり，例忞ば長期電 源計画の最適化のためにっこうした手法を開発した Booth $5^{(3)}$ の例がある。また Bloom ${ }^{(4)}$ は, 一期間内 における確率的モデルと全期間にわたる線形計画法を 組合せることにより, 長期電源計画を解く方法を開発 した。本研究の目的は，このような手法を開発するこ とではなく，不確実な需要の下での分散形電源の価值 を評価し，分散形電源の導入により，電源構成に柔軟 性を与える可能性を検討することにある。その点で不 確実な需要下での電源計画を確率計画問題として定式 化し, 求解にシナリオ統合アルゴリズムを用いた喜多 らの研究 ${ }^{(5)}$ は注目に值する。本研究は文献 $(5)$ と比 較して，多段決定問題として定式化している点や，確 率モデルに対数正規分布を用いることにより需要の確 率分布が連続的に与えられる点などの相違がある。

\section{2. 分散形電源の利点とモデルの前提条件}

〈2・1〉 分散形電源の利点一般的にいって, 分 散形電源の利点は以下の 4 点にまとめられる。

(1)送電コストが低減される。（2）熱供給によって 総合効率が问上する。(3)供給規模調整に関し, 融通 がきく。单位電源規模がかさいと必要需要規模に対し て小回りのきく対応ができる。(4)建設期間が短い。 建設期間が短いので需要不確実性に対応しやすく，予 期せぬ変動に上り生ずる損失が少ない。

電学論 $C, 111$ 巻 8 号, 平成 3 年
本研究は需要の不確実性に焦点をあてており，（1） の送電費用の低減については現在のところ考慮されて いない。し加し，送電費用の分析については森(6)の ような研究があり，送電費用の低減は分散形電源の利 点を評価するうえで重要である。従って，送電費用の 低減を本研究の結果とどのように統合し総合的な評価 を行うかは, 今後の重要な課題である。(2)について

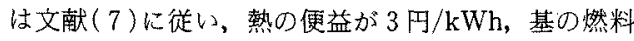
費（天然がスを仮定）が 10 円/kWhであることを考 慮し 7 円/kWh とした。（4）の建設期間の短期性につ いては, 電力需要の長期予测が非常に難しい現在の状 況でこそ，第 1 章で述べた大規模電源と分散形電源の 相補性が見られる可能性がある。そこで本論文では, (4)に焦点をあて[( 3$)$ 毛考慮に入れて , 不確実な需 要下での最適規模構成を求める。以下に計算の前提条 件を説明する。

〈2・2〉 モデルの前提条件

（1）電源の種類音ず，大規模電源と分散形電 源の二種類があると仮定する。二種類の電源の前提条 件としては以下のように仮定する。大規模電源の各条 件は，その典型的な例である原子力発電（㪕水炉）に 基ついて設定している。ただし, 分散形電源の建設単 洒は, 電源の種別と将来の技術開発動问により変動が 予測されるため，パラメータとし，感度分析を行って いる。

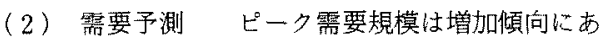
って, 各年の增加率は正規分布に従い, 各年の増加率 の間には相関がないと仮定する。またピーク以外の 需要部分洨，ピーク部分と同じ増加率で伸びていくと 仮定する。その際の前提条件は，以下のと扔りであ る。電力の供給規模としては, 1985 年の $A$ 電力会社 程度の規模（表 2 参照）を考え，需要の伸び率と標準 偏差は, 1980 1987 年の電力 9 社の全電力需要を基 に算定した。電力の点荷持続曲線は 1985 年の電力 9 社のデー夕を基に図1のように折れ線近似している。

表 1 電源の種別之前提条件

Table 1. Assumptions on power plants.

\begin{tabular}{|c|c|c|}
\hline & 大視懵電源 & 分散形電源 \\
\hline 笚位規模 & 110 万 $\mathrm{kW}$ & $2,000 \mathrm{~kW}$ \\
\hline 計画期間 & 5 年 & $/$ \\
\hline 建設期間 & 7 年 & 1 年 \\
\hline 酎用年数 & 30 年 & 30年 \\
\hline 建設単何 & $305 \mathrm{H} / \mathrm{kW}$ & $a_{2}$ 万円 $/ \mathrm{kW}$ \\
\hline 利子率 & \multicolumn{2}{|c|}{$8 \%$} \\
\hline 柋経非率 & $20 \%$ & $20 \%$ \\
\hline
\end{tabular}


表 2 電力需要の増加に関寸る前提条件

Table 2. Assumptions on demands for electricity.

\begin{tabular}{|c|c|}
\hline 初期封点の電力霹要規模 (最大) & 3,500 万 $\mathrm{kW}$ \\
\hline 初期時点の供給設備签墨 & 3,850 万 $\mathrm{kW}$ \\
\hline 需要の平均伸ざ率 $u$ & $3.9 \%$ \\
\hline 需要伸ざ率の標集偏差 $\sigma_{G}$ & $3.2 \%$ \\
\hline
\end{tabular}

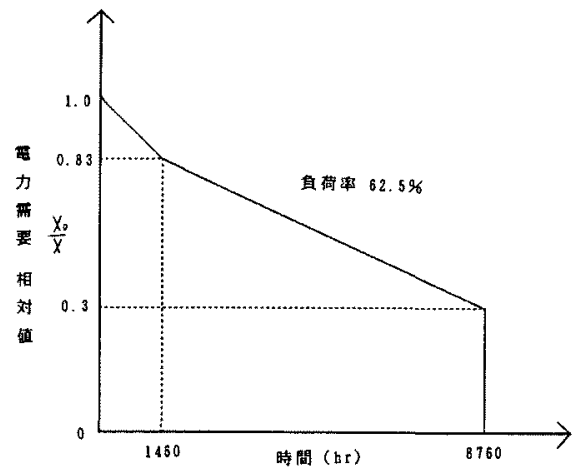

図 1 折れ線近似された負荷持続曲線

Fig. 1. The load duration curve for electricity demands.

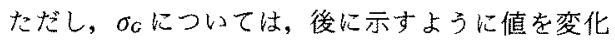
させて感度分析を行っている。このとき， $t$ 年後の需 要 $D(t)$ は $t-1$ 年後の需要 $D(t-1)$ を用いて(1)式 のように表される。

$$
\left.\begin{array}{rl}
D(t) & =D(t-1) e^{u+\varepsilon} \\
\varepsilon & \in N \quad\left(0, \sigma_{G}^{2}\right)
\end{array}\right\}
$$

従って,ピーク需要規模は対数正規分布に従う。

この場合, $T$ 年後の需要の予測は, 上式の対数正 規分布の積となる。

$$
\left.\begin{array}{rl}
D(t+T) & =D(t) e^{u+\zeta} \\
\zeta & \in N\left(0, T{\sigma_{C}}^{2}\right)
\end{array}\right\}
$$

ここでは，らが $T$ 個の独立正規確率変数 $\varepsilon の$ 和で あるため, $\zeta \in N\left(0, T \sigma_{G}{ }^{2}\right)$ となる。つまり，T年後 の需要も京た対数正規分布に従う。従って， $T$ 年後 のピーク需要規模を $x$ とすると, 需要の確率密度変 数 $f(x)$ は，以下のように表される。

$$
\begin{aligned}
& f(x)= \frac{1}{(2 \pi)^{1 / 2} \times x \times T^{1 / 2} \times \sigma_{C}} \\
& \times \exp \left\{\frac{(\log x-\mu)^{2}}{2 \times T \sigma_{C}{ }^{2}}\right\} \\
& \text { ただし, } \mu=3,500 \times \exp (u \times T)
\end{aligned}
$$

\section{3. 最適規模構成の評価基準}

〈3・1〉評洒基準式 電気事業者が $t$ 年後の必要 な供給設備の規模を決めるために，需要の予測に基す いてその時点での系統の総責用, すなわち固定費と可 変費, および需給調整コストの合計が最小になること を最適規模構成決定の評価基準とする。すなわち、コ スト評価基準は次式のようになる。

$$
\begin{aligned}
T C= & \gamma_{1} \times C_{1} \times a_{1} \times \alpha+\gamma_{2} \times C_{2} \times a_{2} \\
& +V_{1} \times F\left(C_{1}\right)+V_{2} \times G\left(C_{2}\right)+C_{S} \\
& \longrightarrow \min \quad \ldots \ldots \ldots \ldots \ldots \ldots \ldots \ldots \ldots \ldots \ldots \ldots \ldots \ldots \ldots \ldots \ldots \ldots \ldots \ldots \ldots
\end{aligned}
$$

たたし， $a_{1}, a_{2}$ : 大規模，分散形電源の建設 単価 $($ 円 $/ \mathrm{kW}), C_{1}, C_{2}$ : 大規模, 分散形電 源の総設備容量 $(\mathrm{kW}), F\left(C_{1}\right), G\left(C_{2}\right)$ : 大 規模電源，分散形電源それぞれの設倩容量に よって決まる発電量 $(\mathrm{kWh}), \gamma_{1}, \gamma_{2}$ : 大規模 電源，分散形電源の経費率， $\alpha$ : 建設中の金 利によるコスト增加率 ( $(10)$ 式参照 $], V_{1}$, $V_{2}$ : 大規模電源，分散形電源の可变費 (円) $\mathrm{kWh}), C_{S}:$ 需給調整コスト(円) ただし，需給調整コストは需給関係がひつ迫して供給 が需要に追い付かないと予測されるときに発生する。

表 1 に示したように，大規模電源は計画から運用開 始までのリードタイムが（計画期間と運用期間を合せ て）合計 12 年かかるとしている。従って，大規模電 源の計画は運用開始の 12 年前に決定する必要がある。 そこで，第 4 章で結果を示す静学的な分析では，12 年後の大規模電源の最適設備容量を決定する問題を取 扱う。その場合，(4)式に扔けるC $C_{1}$ が決定変数とな る。一方，分散形電源のリードタイムは 1 年と仮定し ているため, 11 年後にその年までの需要の伸びを見 たうえで決定することになる。従って，大規模電源の 設備容量を決定する段階では，分散形電源の導入量は 確率変数として与えられることになる。また，需要に 不確実性があるため, それぞれの電源の可変費および 供給不足コストもまた確率変数となる。それ的え，静 学的な分析では（4）式の期待值が最小になることが評 価基準となる。すなわち（5)式のようになる。

$$
\begin{aligned}
E(T C) & \\
= & E\left[\gamma_{1} \times C_{1} \times a_{1} \times \alpha+\gamma_{2} \times C_{2} \times a_{2}\right. \\
& \left.+V_{1} \times F\left(C_{1}\right)+V_{2} \times G\left(C_{2}\right)+C_{S}\right] \\
= & \left\{\gamma_{1} \times C_{1} \times a_{1} \times \alpha+\gamma_{2} \times E\left[C_{2}\right] \times a_{2}+V_{1}\right. \\
& \left.\times E\left[F\left(C_{1}\right)\right]+V_{2} \times E\left[G\left(C_{2}\right)\right]+E\left[C_{S}\right]\right\}
\end{aligned}
$$

動学的な分析では, 計画期間を 12 年後〜 20 年後ま 
てととし，期間中の累積費用の期待值が最小になること を評価基準とする。すなわち， $i$ 期に㭁汸る総費用を $T C_{i}$ とすると，(6)式のような評価基準が得られる。

$$
\begin{aligned}
E_{i}\left[\Sigma T C_{i}\right]=\sum_{i} E\left[T C_{i}\right] \\
=\sum_{i}\left(\gamma_{1} \times C_{1}(i) \times a_{1} \times \alpha+\gamma_{2} \times E\left[C_{2}(i)\right] \times a_{2}\right. \\
\quad+V_{1} \times E\left[F\left(C_{1}(i)\right)\right]+V_{2} \times E\left[G\left(C_{2}(i)\right)\right] \\
\left.\quad+E\left[C_{s}(i)\right]\right\} \quad \cdots \cdots \cdots \cdots \cdots \cdots \cdots \cdots \cdots \cdots \cdots \cdots \cdots \cdots \cdots \cdots \cdots \cdots \cdots \cdots
\end{aligned}
$$

ただし，ここで各年の大規模電源の設䚛容量は非減少 てなければならないから（7）式の制約が加わる。

$$
C_{1}(i+1) \geqq C_{1}(i) \quad(1 \leqq i \leqq n-1)
$$

一方, 分散形電源の各年の設備容量は, 上に述べた ように，確率変数としてしか与えられない。そのた め, 分散形電源については, 設備容量の期待値が非減 少でなければならないという制約 $[(8)$ 式〕を加えた。

$$
E\left[C_{2}(i+1)\right] \geqq E\left[C_{2}(i)\right] \quad(1 \leqq i \leqq n-1)
$$

(7)，（8)式の制約の下で，(6)式を最小にする大規 模電源の設備容量 $\left\{C_{1}(i), 1 \leqq i \leqq n-1\right\}$ を決定する問 題汸多段決定問題に帰着し, 最適性の原理より次式が 成り立つ。

$$
\begin{aligned}
& \left\{\sum_{i=1}^{n} E[T C(i)]\right\}_{\min } \\
& =\left[\left\{\sum_{i=1}^{n-1} E[T C(i)]\right\}_{\min }+E[T C(n)]\right]_{\min }
\end{aligned}
$$

第 5 章で結果を示す動学的な分析に扔いては，(6)式 のような評価基準の下での多段决定問題を解くことに なる。以下に，(4)〜 (9)式で変数として用いられた 固定費, 可変費, 供給不足コス卜の算定方法を説明す る。

\section{〈3・2〉固定費，可变費および供給不足コストの}

\section{算定方法}

（1）金利計算 電源の固定費算出に際しては, 建設中の金利によるコスト增加分（いわ的る建中利 子）を算定しなければならない。この建中利子の算定 には, 表 1 に掲げたような建設期問と耐用年数の值を 用いている。なお，分散形電源は建設期間が 1 年とし ているため, 建中利子は発生しない。大規模電源の場 合，建設開始後完了亲で每年同額の投資コストが必要 であるとして，複利計算で以下のように金利によるコ ス下增分を算出している。

$$
\begin{aligned}
\begin{aligned}
\sum_{j=1}^{T-1} \frac{C_{1}}{T} \times a_{1} \times(1+r)^{j} & =\frac{C_{1}}{T} \times a_{1} \times \frac{(1+r)^{T}-1}{r} \\
& =C_{1} \times a_{1} \times a \cdots \cdots(10)
\end{aligned} \\
\text { ここで, } T: \text { 建設年数, } r: \text { 年利子率 }
\end{aligned}
$$

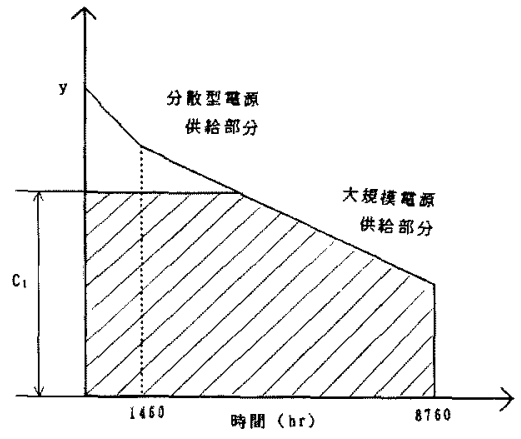

図 2 需要に対する大規模電源と分散形電源の分担

Fig. 2. Shares of large and small scale plants.

（2）固定費，可変費および供給不足コストの算出 固定費招上び可変費の算定屾以下の筋道で行う。ま ず，電力の負荷持続曲線を，1985 年の $A$ 電力会社 デー夕を基に図 1 のように近似し，同図で表される電 力需要を䝵うことを考える。前述したように，大規模 電源のリードタイムは 12 年と仮定しているから， 12 年後を考慮してその年の最適な建設 (計画) 容量を決 定しなければならない。ただし，実際には計画の前倒 しや建設期關の延長でリード夕イムをある程度可変と することができる。このような融通性は大規模電源の 相対的価值を高めると考えられるが，この点をモデル に取入れることは今後の研究囬題である。この場合， 大規模電源のほうが分散形電源より可変費が低いの で，図20ように大規模電源はベース部分を賄う。

一方, 分散形電源のリードタイムは 1 年と仮定して いるから，目標年の前年にその年の最適な設備容量を 決定すればよい。従って, 計画開始時点から11年後 のピーク電力需要を $x$ とすると, 分散形電源の目標 年 (計画開始時点から 12 年後) における設備容量 $C_{2}$ は， $x$ の関数となる。系統全体の固定蕒は， $C_{1}$ と $C_{2}(x)$ を用いて(11)式のように表される。系統全体の 可変費法， $C_{1}, C_{2}(x)$ および目標年に㧍けるピーク電 力需要 $y$ を用いて，(12)式のように表される。たた し, 関数 $S\left(y, C_{1}\right)$ は, 図 2 においてピーク需要規模 が $y$ あるときのハッチ部分の面積を表し，それは， 大規模電源に上る発電量 $(\mathrm{kWh})$ を意味する。

固定費 : $a_{1} \times C_{1} \times \alpha \times \gamma_{1}+a_{2} \times C_{2}(x) \times \gamma_{2}$

$$
\begin{aligned}
& \text { 可変費: } S\left(y, C_{1}\right) \times V_{1}+\left\{S\left(y, C_{1}+C_{2}\right)\right. \\
& \left.-S\left(y, C_{1}\right)\right\} \times V_{2}
\end{aligned}
$$

目標年におけるピーク電力需要 $y$ は, 11 年後のピ 
一ク電力需要 $x$ の関数となる。 $x, y$ の確率密度関数 は，(3)式を基に(13)，(14)式のように表される。

$$
\begin{aligned}
f(x)= & \frac{1}{(2 \pi)^{1 / 2} \times x \times T^{1 / 2} \times \sigma_{G}} \\
& \times \exp \left\{\frac{\left(\log x-\mu_{1}\right)^{2}}{2 \times T \sigma_{G}{ }^{2}}\right\}
\end{aligned}
$$

ただし，

$$
\mu_{1}=3,500 \times \exp (u \times T), T=11
$$

$$
g(y)=\frac{1}{(2 \pi)^{1 / 2} \times y \times \sigma_{G}} \exp \left\{\frac{\left(\log y-\mu_{2}\right)^{2}}{2 \times \sigma_{G}{ }^{2}}\right\}
$$

ただし，

$$
\mu_{2}=x \times \exp (u)
$$

最後に, $C_{1}, C_{2}(x)$ 抢よび目標年におけるピーク電 力需要 $y$ から供給不足コス卜を導く。電力需要が, 供給規模を上回ると予測した場合，電気事業者は大口 需要家に負荷調整を要望し, 調節する。その際のコス トとしては，例充ば厚生経済学における消費者余剩の 概念を用いて，著者らが算出した例がある(2)。これ は, 大口産業需要家の規模, 件数, 需要の価格弾性值 から需要曲線をちえることによって，算出できる。し 加し，実際には価格弾性值は需要家によって異なるこ と, 需要量が 0 に近づくと需要曲線が定義できないな ど問題もある。そこで，ここでは单位供給不足量に対 するコスト，C C 給不足コストに関しては多くの調査があり ${ }^{(8)}$, 需要の 種類などにより異なる。ここでは，すべての需要での 供給不足コストを平均した現実的な值として $C_{s u}=$ 1,000 円 $/ \mathrm{kWh}$ とする ${ }^{(9)}$ ，本研究ては，需要の增加率 の不確実性に焦点をあてているため，供給不足コスト に関する感度分析は行っていないが，この点は今後の 研究課題である。この場合，系統全体としてのある時 点における供給不足コストは(14)式で表される。

$$
\begin{array}{r}
C_{s}=\operatorname{sgn}\left\{S(y, y)-S\left(y, C_{1}+C_{2}\right)\right\}\{S(y, y) \\
\left.-S\left(y, C_{1}+C_{2}\right)\right\} \times C_{s u} \cdots \cdots \cdots \cdots \cdots(15) \\
\text { ただし, } \operatorname{sgn}(x)=\left\{\begin{array}{ll}
1 & \text { if } x \geqq 0 \\
0 & \text { if } x>0
\end{array}, C_{s u}=1,000\right.
\end{array}
$$

系統全体の固定費, 可変費, 供給不足コスト〔それ ぞれ(11)，(12)，(15)式了と $x, y$ の確率密度関数よ り，(5)式で示した総費用の期待值は，実際には(16) 式の上うに表されることがわかる。

$$
\begin{aligned}
& E(T C)= \\
& \quad \int d x\left[f(x) \times \int d y\left\{g(y) \times\left[a_{1} \times C_{1} \times \alpha \times \gamma_{1}\right.\right.\right. \\
& \quad+a_{2} \times C_{2}(x) \times \gamma_{2}+S\left(y, C_{1}\right) \times V_{1} \\
& \quad+\left\{S\left(y, C_{1}+C_{2}\right)-S\left(y, C_{1}\right)\right\} \times V_{2} \\
& \quad+\operatorname{sgn}\left\{S(y, y)-S\left(y, C_{1}+C_{2}\right)\right\}\{S(y, y)
\end{aligned}
$$

$$
\left.\left.\left.\left.-S\left(y, C_{1}+C_{2}\right)\right\} C_{s u}\right)\right\}\right]
$$

(13)，（14）式を(16)式に代入することにより，静学的 分析における評価基準式が得られる。また，各期にお ける(16)式の値を算定することにより, 動学的分析に おける評価基準值が得られる。

\section{4. 静学的分析}

以上のような定式化の下で，まず静学的な分析を行

\begin{tabular}{|c|c|c|}
\hline$a_{1}$ & 大規模電海の建設単価 & 300,000 辛 $/ \mathrm{kW}$ \\
\hline$a_{2}$ & 分散形霔源の建設単洒 & パラメータ $¥ / \mathrm{kW}$ \\
\hline$r_{i}$ & 大䙺模電源の年経蛪率 & 0.20 \\
\hline$r_{2}$ & 分散形電源の年経費率 & 0.20 \\
\hline$\alpha$ & 建中利子によるコス卜增加率 & 1.27 \\
\hline$V_{1}$ & 大規模電源の可疂費 & $3.26 * / \mathrm{kWh}$ \\
\hline$V_{z}$ & 分散形電源の可変㛝 & $7.0 \pm / \mathrm{kWh}$ \\
\hline$C_{s u}$ & 供給不足コスト & $1,000 ¥ / \mathrm{kWh}$ \\
\hline$u$ & 需要の平均伸び率 & $3.9 \%$ \\
\hline$\sigma_{i}$ & 霜要伸び率の標準価差 & $3.2 \%$ \\
\hline \multirow[t]{2}{*}{$\begin{array}{l}\text { 篗 } \\
\text { 背 }\end{array}$} & \multicolumn{2}{|l|}{ "O. O o o opt. 00000} \\
\hline & 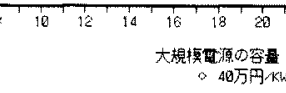 & 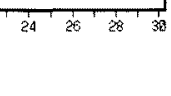 \\
\hline
\end{tabular}
った。ただし，計算に用いたパラメータの值は表 $3 の$ とおりである。

計算の結果, 大規模電源の設備容量と分散形電源を

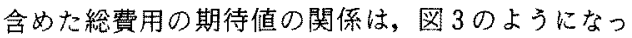
た。図中で総費用の期待値が最小になる点が大規模電 源の最適な設備容量を与える。

分散形電源の建設単洒を变化させた場合の結果を, 図 4 に示す。また，総費用の期待值が最小となるとき の大規模電源の総設備容量に対する比率の期待值を, 図 5 に示す。分散形電源の建設単価が大きいほど大規 模電源の最適設備容量が大きくなり，その比率が高く

表 3 パラメー夕值

Table 3. Values of parameters.

份散形雨源の建設単価が 40 万円 $/ \mathrm{kW}$ の場合

困 3 大規模電源の設備容量と総費用の 期待值の関係

Fig. 3. The expexted values of total costs as a function of the number of large scale plants. 


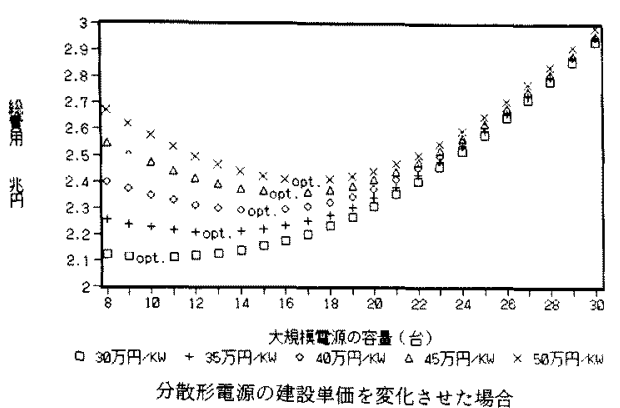

図 4 大規模電源の設埆容量と総費用の 期待値の関係

Fig. 4. The expected values of total costs as a function of the number of large scale plants.

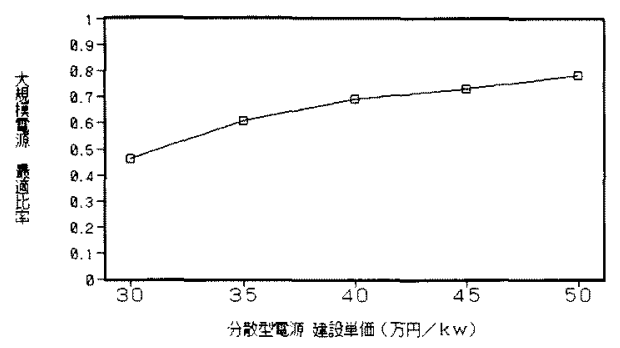

図 5 最適な大規模電源の比率の期待値と 分散形電源の建設単価の関係

Fig. 5. The optimal shares of large scale plants as a function of construction costs for small scale plants.

なることは当然である。図で, 分散形電源の建設単価 が36万円/kW以上になると，建中利子を考慮に入 れても固定費が大規模電源を上回り，また可変費も 〈3・2〉節で述べたように，分散形電源のほうが高い。 しかし, 図 4 , 図5は，この上うな場合でも, 将来の需要 に不確実性がある場合には，大規模電源を総供給容輿 より若干少な目につくり，残りを分散形電源で補うほ うが，経済的に有利であることを示唆している。

この結果が不確実性を考慮したためであるというこ とを確かめるために，原を变化させ結果を比較する。 最適な大規模電源の比率と $\sigma_{C}$ の関係を図 6 に示す。 $\sigma_{G}=0$ で, 分散形電源の建設筆洒が高い場合 $(40$ 万 円 $/ \mathrm{kW}$ 以上）に法，大規模電源の比率が $100 \%$ とな っても不思議ではないが，図6で 100\%となってはい ない。大規模電源は一基あたりの規模が 110 万W であるため, 需要増加䤃を大規模電源の単位規模であ る 110 万 kWで除した剩余分（この場合は 49 万

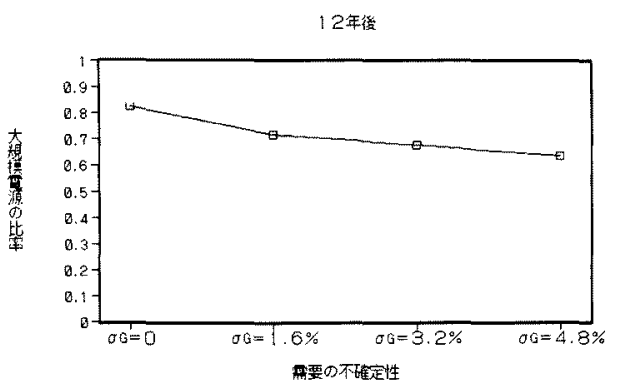

図 6 最適な大規模電源の比率の期待值と $\sigma_{G}$ との関係

Fig. 6. The optimal share of large scale plants as a function of $\sigma_{G}$.

$\mathrm{kW}$ ）を補うために一基增設するとむだが生ずる。そ のたに，わずかではあが高コストの分散形電源が導 入きれているのである。

\section{5. 動学的分析}

奏際の電源計画は 20 年程度の動的枠組みの中で議 論されることが多い。静学的分析の結果として得られ た大規模電源と分散形電源の分担は，動学的分析にお いても同様であるうか。この点を確かめるため，第 3 章で述べた定式化の下での多段決定問題を解く。需要 の增加については静学的分析と同様に $u=3.9 \%, \sigma_{G}$ $=3.2 \%$ と設定し, 分散形電源の建設単価を変化させ た場合の多段決定問題の解を図 7 に示す。

図 7 より, 12 年後の大規模電源の設備容量を, 静 学的分析の結果（図 4 参照）と比較すると，両者は等 しくなっていることがわかる。従って，12 年後の一 断面のみに打付る大規模電源と分散形電源の分担を考 える場合には，静学的分析の結果は有効であるといえ る。しかし, 静学的分析では 12 年後以降の電源構成 については，示唆を得ることはできない。図 8 は，大 規模電源の最適な比率の期待值の推移を表すが, これ 上り最適な比率の期待値は徐々に增加していくことが わかる。

次に，静学的分析と同じように不確実性がない場合 と比較してみる。需要の不確実性がない場合の大規模 電源の最適設備容量を求める問題は通常の多段决定問 題に帰着する。基本的な定式化は不確実性がある場合 と同様であり，前の定式化で期待值として扱っていた 分散形電源の固定費, 総可変費, 供給不足コス卜を確 定値として扱うことになる。分散形電源の建設単価が 40 万円 $/ \mathrm{kW}$ の場合について, 確率的多段決定問題の 解と（確定的）多段决定問題の解を比較した結果を図

電学論C, 111 巻 8 号, 平成 3 年 


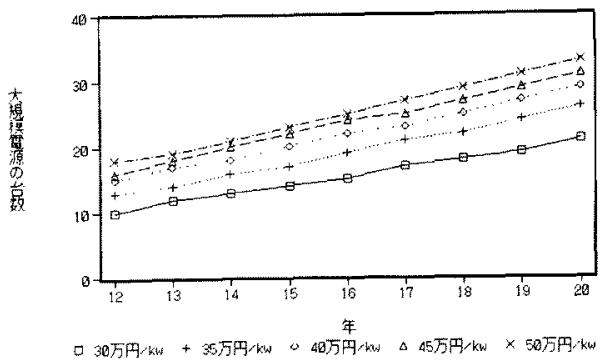

図 7 大規模電源の舅適設備容量の推移

Fig. 7. The optimal capacity of large scale plants.

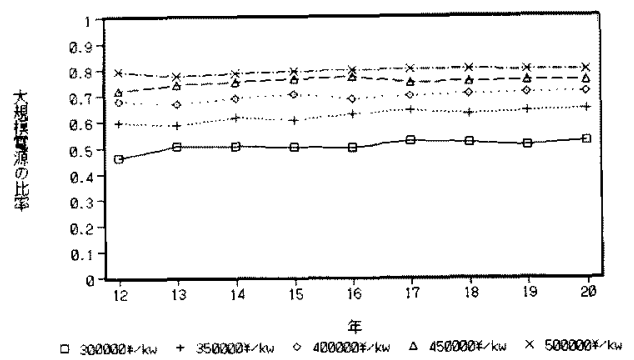

図 8 大規模電源の最適な比率の期待值の推移

Fig. 8. The optimal share of large scale plants.

9 に，各々の場合の累積費用の期待值を図 10 に示す。

図 9 より，大規模電源 $\sigma$ 最適規模は, $\sigma c$ が 1.6〜4.8\%ではあまり変化しないことがわかる。これ は, 需要の不確奏性が大きいほど必要な電源の総供給 容量が大きくなることと，大規模電源が相対的に不利 になって，その全体に対する割合が小さくなることが 相殺するためである。また，当然のことながら，不確 実性が大きいほど総費用の期待值が出化することが图 10 上りわかる。目標最終年次(計画開始から20年 後）に㤂ける大規模電源の最適な比率の期待值と $\sigma_{c}$ の関係を図 11 に示す。需要の不確夷性を考慮した計 画と考慮しない場合の計画では，特に分散形電源の必 要性に相当の差がでることがわかる。〈2・2〉節 ( 2 項 で述べたうに，1980〜1987年の電力需要のデータ では $\sigma_{G}=3.2 \%$ であから，それに対応する分散形電 源の比率は 20 年後において約 $28 \%$ になる。

これらの結果から，需要の不確実性を考慮した計画 では, 将来需要の中で不確実性の大きい部分を分散形 電源で補い，確実な部分を大規模電源で䝵うという， 直観的に理解しやすい解が得られていることがわか る。すなわち，低コストだがリードタイムの長い大規 模電源と, 高コストだがリードタイムの短い分散形電

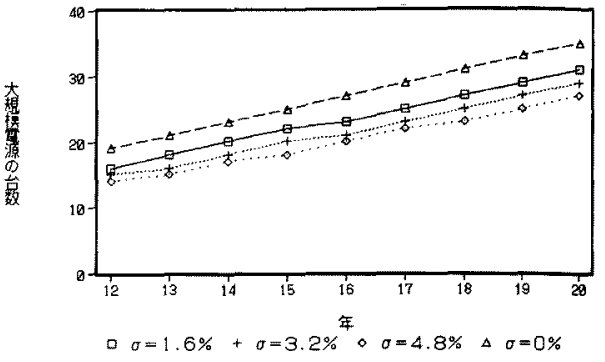

図 $9 \sigma_{\mathrm{C}}$ が変化した場合の最適設備容量 の推移

Fig. 9. The optimal capacity of large scale plants as a function of $\sigma_{G}$.

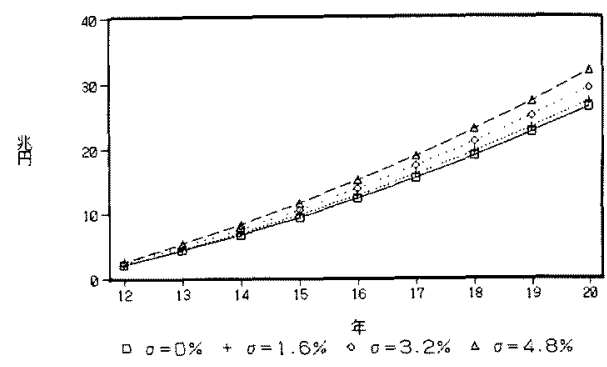

図 10 需要の不確実性が変化した場合の 累積畫用の期待値の推移

Fig. 10. The expected values of accumulated total costs as functions of $\sigma_{c}$.

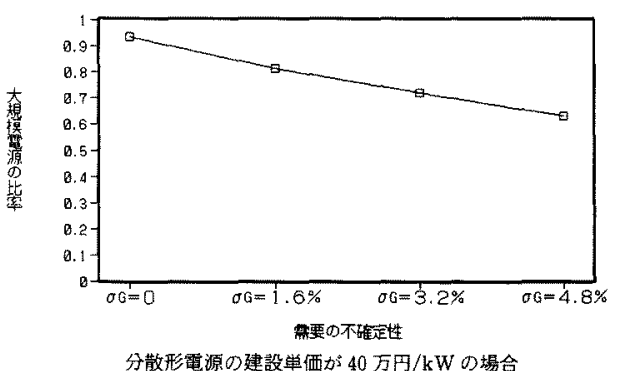

図 11 目標最終年次における大規模電源の

最適な上率の期待值と $\sigma_{G}$ の関係

Fig. 11. The optimal share of large scale plants as a function of $\sigma_{G}$.

源が，相補って需要の不確実性に対応しているわけで ある。

6.むすび

本研究では，電源における規模の経済性の問題に着

T. IEE Japan, Vol. 111-C, No. 8, '91 
目し, 近年燃料電池など技術の進歩が目覚ましい分散 形電源によって規模の不経済を補うことを考えた。特 に将来の電力需要に不確実性がある場合に, リード夕 イムが長い大規模電源に対し, 比較的短期間で建設で きると考えられる分散形電源の利点を定量的に評価し た。具体的には, 大規模と分散形電源の二種で成り立 つ単純化された電源構成モデルを構築した。まず，静 学的な分析において目標年度の電源の総費用の期待値 を最小化するような電源構成を求めた。これを需要の 不確実性がない場合と比較し, 不確実性がある場合に 分散形電源が割高でも重要な役割を果たし得ることを 確認した。次に，動学的な枠組みにおいて累積費用の 期待值を最小化する電源構成の推移を確率的多段決定 問題の解として求めた。これらの分析から，低コスト だがリードタイムの長い大規模電源と, 高コストだが リードタイムの短い分散形電源が, 相補って需要の不 確実性に対応しうることが確認された。

現実には電源は二種類以上あり, 需要の不確実性へ の対応策も, 本研究で示した以外に様々なものが考元 られる。その場合でも, リードタイムの短い分散形電 源は重要な役割を果たし得るであろう。また，現在ピ 一ク用電源としては石油火力発電などが用いられてい るが，分散形電源をコージェネレーションとして用 い，一部でも石油火力に代替することにより，システ 厶全体としても効率が高まり, 地球温暖化問題への対 策にもつながる。その意味からも分散形電源の系統へ の導入を検討しなければならない。本研究の結果は, このような特色をもつ分散形電源を, 積極的に導入す る一つの有効な根拠を与え得るものである。

今後は, 電源構成のモデルをより現実に近づけてい きたい。また，需要のみならず（電源の計画外事故な どによる）供給の不確実性が電源構成に与える影響も 検討していく予定である。

(平成 2 年 12 月 25 日受付, 同 3 年 4 月 8 日再受付)

$$
\text { 文献 }
$$

（1）松橋・武智・林・茅:「発電所における規模の経济性について」, エネルギー資源研究会第 7 回講演論文集 (昭 63)

(2) Y. Kaya, T. Hayashi \& X. Lu: "Economc Evaluation of Flexibility of Small Scale Electric Power Plants", IFAC 10th World Conference (1987)

(3) R. R. Booth: "Optimal Approach to Generation Planning Considering Uncertainty", IEEE, Trans. Power Apparatus Syst., PAS-91, 70 (1972)

(4) J. A. Bloom: "Long Range Generation Planning Using Decomposition and Probabilistic Simulations", ibid., PAS-101, 797(1982)

（5）喜多・手塚・西川・中野: 「不確実な需要下での小規模電源の 可能性について」，第 7 回エネルギーシステム経済コンファ レンス講演論文集, p. 171 (平 2)

（6）森:「電源設備のスケールメリットと最適配置について」, 第
5 回エネルギーシステム経済コンファレンス講演論文集, p.41(昭 63)

（7）近藤・茅：「季時別料金制度下での自家発電最適運用の基整的 検討」, 平元電気学会全大, 1094

（8）西野・植木・牧野：「わが国における停電コストの評価」，電 中研報告, 582007 (昭 57)

(9) K. Yamaji: "Applications of the Over/Under Model to a Japanese Electric Utility", CRIEPI Report, 電力中央 研究所, E 584005 (昭 59)

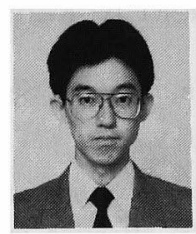

\section{松 橋 隆 治 (正員)}

平成 2 年 3 月東京大学大学院工学 系研究科電気工学専攻博士課程修 了。平成 2 年 4 月同大学資源開発工 学科助手。工学博士。エネルギーシ ステム，地球温暖化問題を対象とした研究に従事。エ ネルギー資源学会会員。

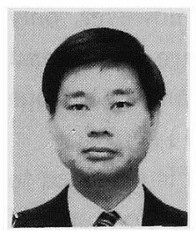

$$
\text { 石谷 久 (正員) }
$$

昭和 44 年東京大学大学院工学系 研究科電気工学専攻博士課程修了。 同年同大学宇宙航空研究所勤務。同 研究所講師, 助教授を経て 56 年よ り同大学工学部, 63 年同大学先端科学技術研究セン 夕一勤務。6 64 年東京大学工学部資源開発工学科教授。 工学博士。制御，システム理論の応用に関する研究に 従事。計測自動制御学会, エネルギー資源学会, IEEE 会員。

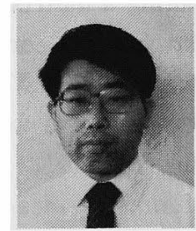

$$
\text { 林武人 (正員) }
$$

昭和 49 年 3 月東京都立大学工学 部電気工学科卒業。39 年 4 月東京 大学工学部電気工学科勤務, 49 年 4 月同助手。システム制御工学, 特に エネルギーシステムを対象とした研究に従事。エネル ギー資源学会会員。

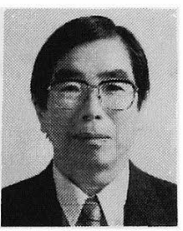

$$
\text { 茅陽 一 (正員) }
$$

昭和 37 年 3 月東京大学大学院工 学系研究科電気工学専攻博士課程修 了。同年 4 月同大学工学部電気工学 科講師, 38 年 4 月同助教授。 53 年 7 月同教授となり，現在に至る。工学博士。システム 制御工学，特に社会システム，エネルギーシテムを対 象とした研究に従事。電子情報通信学会, 計測自動制 御学会, エネルギー資源学会, IEEE 会員。 